\title{
Steroid receptors in the canine epididymis
}

\author{
Muazaz Younes, Bronwen A. J. Evans, N. Chaisiri, \\ Y. Valotaire and C. G. Pierrepoint \\ Tenovus Institute for Cancer Research, Welsh National School of Medicine, \\ Heath Park, Cardiff, CF4 4XX, U.K.
}

\begin{abstract}
Summary. High-affinity and low-capacity molecules that bind $5 a$-dihydrotestosterone and oestradiol-17 $\beta$ have been demonstrated in the canine epididymis. The molecules were shown to be proteinaceous in nature, thermolabile and sedimented in a sucrose density gradient with a coefficient of $8 \mathrm{~S}$ with respect to bovine serum albumin.

Only minor differences were found for dissociation constants for oestradiol-17 $\beta$ $\left(3.5 \pm 2.74 \times 10^{-10} \mathrm{M}\right)$ and $5 \alpha$-dihydrotestosterone $\left(4.2 \pm 10.75 \times 10^{-10} \mathrm{M}\right)$ (means \pm s.d.) in the three anatomically distinct regions of the epididymis.
\end{abstract}

\section{Introduction}

It has long been recognized (Benoit, 1926) that the epididymis is dependent upon androgenic hormones for maintenance of its cellular integrity and complex functions (see Hamilton, 1975). Spermatozoa mature in transit along the epididymal duct acquiring fertilizing ability (Nishikawa \& Waide, 1952; Bedford, 1966, 1967; Orgebin-Crist, 1967; Orgebin-Crist, Davies \& Tichenon, 1972). These processes, as well as the maintenance of sperm viability (Lubicz-Nawrocki \& Glover, 1973) are also androgen dependent.

It is becoming accepted that steroid hormones achieve most of their effects in a sequence of complex events initiated by their binding to soluble cytoplasmic receptors in the target organs with subsequent transfer to the nucleus (see Baulieu et al., 1971; O'Malley \& Means, 1974; King \& Mainwaring, 1974). Such androgen-binding proteins, or receptors, have been demonstrated in the epididymis of the rat (Blaquier, Cameo \& Charreau, 1970; Ritzen, Nayfeh, French \& Dobbins, 1971; Blaquier, 1971; Hansson, Djøseland, Reusch, Attramadal \& Torgerson, 1973b) and rabbit (Danzo, Orgebin-Crist \& Toft, 1973; Danzo \& Eller, 1975). The epididymis of immature rats and rabbits has also been found to contain a binding component for oestradiol$17 \beta$ (Danzo, Eller \& Judy, 1975; Danzo, Wolfe \& Curry, 1977).

As a part of a larger study of the endocrine control of target organs of the dog and because the epididymis may have a direct influence on the prostate (Pierrepoint, Davies \& Wilson, 1974), the canine epididymis was examined for androgen and oestrogen receptors.

\section{Materials and Methods}

$\left[1,2,4,5,6,7,(\mathrm{n}){ }^{3} \mathrm{H}\right] 5 \alpha$-Dihydrotestosterone (sp. act. $\left.127 \mathrm{Ci} / \mathrm{mmol}\right)$ and $\left[2,4,6,7,(\mathrm{n})-{ }^{3} \mathrm{H}\right]$ oestradiol-17 $\beta$ (sp. act. $109 \mathrm{Ci} / \mathrm{mmol}$ ) were obtained from the Radiochemical Centre, Amersham, Bucks. Dithiothreitol and bovine serum albumin (BSA) were supplied by Sigma Chemical Co. Ltd, London whilst the diethylstilboestrol (DES) was purchased from the Koch-Light Laboratories Ltd, Colnbrook, Bucks. Cyproterone acetate and $5 \alpha$-androstane-3 $3,17 \alpha$-diol were gifts from Schering Chemicals Ltd, Burgess Hill, Sussex. Flutamide and $\alpha, \alpha, \alpha$,trifluoro-2-methyl-4 ${ }^{1}$ nitro-m-lacto-toluidine were generously donated by the Schering Corporation, Bloomfield, New 
Jersey, U.S.A. Other unlabelled steroids were purchased from the Sigma Chemical Co., as were the enzymes RNase, DNase and protease (Subtilisin, Carlsberg). Dextran T70 was bought from Pharmacia Fine Chemicals, Sweden, and charcoal (Norit GSX) from Hopkins \& Williams, Essex. The synthetic androgen R1881 was a generous gift from Dr J.-P. Raynaud, RousselUclaf, Romainville, France.

Epididymides were obtained from entire, orchidectomized or diethylstilboestrol-treated (25 $\mathrm{mg}$ /day subcutaneously for 4 days) dogs of no particular breed. Castrations were performed under sodium pentobarbitone (Nembutal: Abbott) anaesthesia without interference with epididymal blood vessels. The organs were placed immediately on ice and all procedures were then carried out at $0-4^{\circ} \mathrm{C}$ unless otherwise stated. After removal of adherent fat and connective tissue the epididymides were rinsed in Buffer A (50 mM-Tris-HCl, 0.1 mM-EDTA, 0.25 mMdithiothreitol, $\mathrm{pH}$ 7.4) and weighed.

The tissue was finely chopped using iridectomy scissors and stirred gently in Buffer A for 30 min, changing the medium at 10 -min intervals to remove spermatozoa. The efficacy of this procedure was assessed by electron microscopy and shown to be valid. A cytosol preparation was achieved by the method of Evans \& Pierrepoint (1975) at a tissue to medium ratio of $1: 3$.

On two occasions epididymides were removed from an entire animal and from a dog that had been orchidectomized 3 days previously, and divided into caput, corpus and cauda epididymidis. Each segment was then treated in the same manner as the whole organ studies to assess binding.

\section{Removal of endogenous steroids}

A modification of the method described by Heyns, Van Baelen \& De Moor (1967) was adopted to remove endogenous steroids from the cytosol before labelling. Dextran-coated charcoal suspensions $(0.5 \%(\mathrm{w} / \mathrm{v})$ Norit GSX, $0.05 \%(\mathrm{w} / \mathrm{v})$ dextran T-70, $0.1 \%(\mathrm{w} / \mathrm{v})$ gelatin in Buffer A) were centrifuged at $800 \mathrm{~g}$ for $10 \mathrm{~min}$. The supernatants were decanted and the cytosol preparations added to the pelleted charcoal at a ratio of $1 \mathrm{mg}$ charcoal : $1 \mathrm{mg}$ cytosol protein. The tubes were shaken for $10 \mathrm{~min}$ at $4^{\circ} \mathrm{C}$ before removing the charcoal by centrifugation for $15 \mathrm{~min}$ at $800 \mathrm{~g}$.

\section{Assessment of binding characteristics}

Cytosol ( $1 \mathrm{ml})$ was incubated with $2 \mathrm{pmol}$ tritiated $5 \alpha$-dihydrotestosterone or oestradiol- $17 \beta$ in the presence and absence of 100 -fold excess of unlabelled steroid at $0^{\circ} \mathrm{C}$ for 4-6 h. Following incubation, the cytosol $(400 \mu \mathrm{l})$ was layered onto 5-20\% sucrose-density gradients prepared in Buffer A and centrifuged at $114000 \mathrm{~g}_{\mathrm{av}}$ for $18 \mathrm{~h}$ (using a Beckman SW 50.1 swinging bucket rotor in an $\mathrm{L}_{2} 65 \mathrm{~B}$ ultracentrifuge). BSA (coefficient of sedimentation $4.6 \mathrm{~S}_{20 \mathrm{w}}, 10 \mathrm{mg} / \mathrm{ml}$ ) was used as an external marker. Fractions ( 3 drops, $180 \mu \mathrm{l}$ ) were collected by upward displacement into scintillation vials and the distribution of bound radioactivity was assessed after the addition of $6 \mathrm{ml}$ scintillation fluid containing toluene-Triton X-100 (2:1 v/v) and $0.5 \%$ PPO $(\mathrm{w} / \mathrm{v})$ in a Nuclear Chicago Mark II liquid scintillation spectrometer. Efficiency of counting was $25-40 \%$.

\section{Evaluation of binding specificity}

Aliquots $(200 \mu \mathrm{l})$ of cytosol were incubated at $0^{\circ} \mathrm{C}$ for $6 \mathrm{~h}$ with an equal volume of Buffer $\mathrm{A}$ containing 1 pmol tritiated $5 \alpha$-dihydrotestosterone or oestradiol- $17 \beta$ and increasing amounts, up to 100 -fold excess of the ligands, of the various competitors. Free and loosely bound material were adsorbed onto dextran-coated charcoal ( $400 \mu$ l suspension for $10 \mathrm{~min})$. The remaining bound radioactivity was assessed as described above. 


\section{Saturation analysis}

Further characteristics of the binding proteins were quantitated by the incubation of cytosol $(200 \mu \mathrm{l})$ at $0^{\circ} \mathrm{C}$ for $6 \mathrm{~h}$ with $200 \mu \mathrm{l}$ Buffer $\mathrm{A}$ and increasing amounts $(0.06-8 \mathrm{pmol})$ of tritiated $5 \alpha$-dihydrotestosterone or oestradiol-17 $\beta$ in the presence and absence of 100 -fold excess of unlabelled ligand. Following incubation the mixtures were treated with dextran-coated charcoal as above and the bound radioactivity assessed. The results were treated according to Scatchard (1949).

\section{Evaluation of the chemical nature of the binding molecules}

Aliquots of cytosol were incubated with tritiated steroid as before and further incubated with and without the inclusion of the enzymes protease, RNase or DNase $(2 \mathrm{mg} / \mathrm{ml})$ for $1 \mathrm{~h}$ at $20^{\circ} \mathrm{C}$.

Other aliquots were warmed at $45^{\circ} \mathrm{C}$ for $20 \mathrm{~min}$, then cooled at $0^{\circ} \mathrm{C}$ before incubating with labelled steroid.

Sucrose density-gradient centrifugation was carried out and radioactive profiles constructed on displacement aliquots as before.

\section{Results}

The profiles of bound radioactivity achieved following the fractionation of cytosol labelled with tritiated $5 \alpha$-dihydrotestosterone or oestradiol-17 $\beta$ are shown in Text-fig. 1. With both hormones, two peaks of macromolecular binding were demonstrated sedimenting in the 4S and $8 \mathrm{~S}$ regions. The binding moieties in the $8 \mathrm{~S}$ regions were shown to be of low capacity by the complete

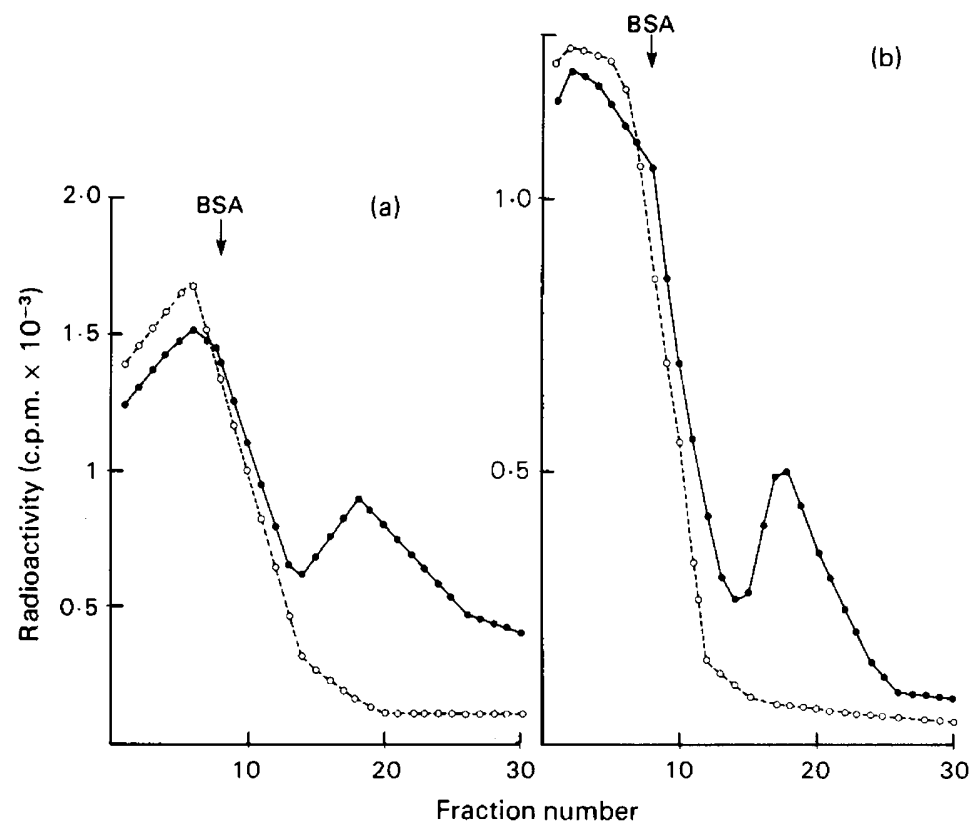

Text-fig. 1. Radioactive profiles from sucrose density-gradient centrifugation of canine epididymal cytosol preincubated with (a) 2 pmol tritiated $5 \alpha$-dihydrotestosterone and (b) 2 pmol tritiated oestradiol-17 $\beta$ alone (O) and in the presence of 200 pmol unlabelled steroid $(O)$. The sedimentation marker is BSA with a coefficient of sedimentation of $4 \cdot 6 \mathrm{~S}$. 
displacement of radioactivity by a 100 -fold excess of unlabelled ligand. Binding in the $4 \mathrm{~S}$ region was apparently unaffected by the excess steroid. When the competing steroids were reversed they were without effect on the binding of the other hormone.

The proteinaceous nature of the binding moieties was demonstrated by the destruction of binding ability after incubating labelled cytosol with the hydrolytic enzyme, protease (Text-fig. 2). A similar result was achieved for the oestradiol-binding protein (not shown). For both hormones DNase and RNase were without effect. The thermolability of the receptors was demonstrated when no binding could be shown following the heating of the cytosol at $45^{\circ} \mathrm{C}$ for $20 \mathrm{~min}$.

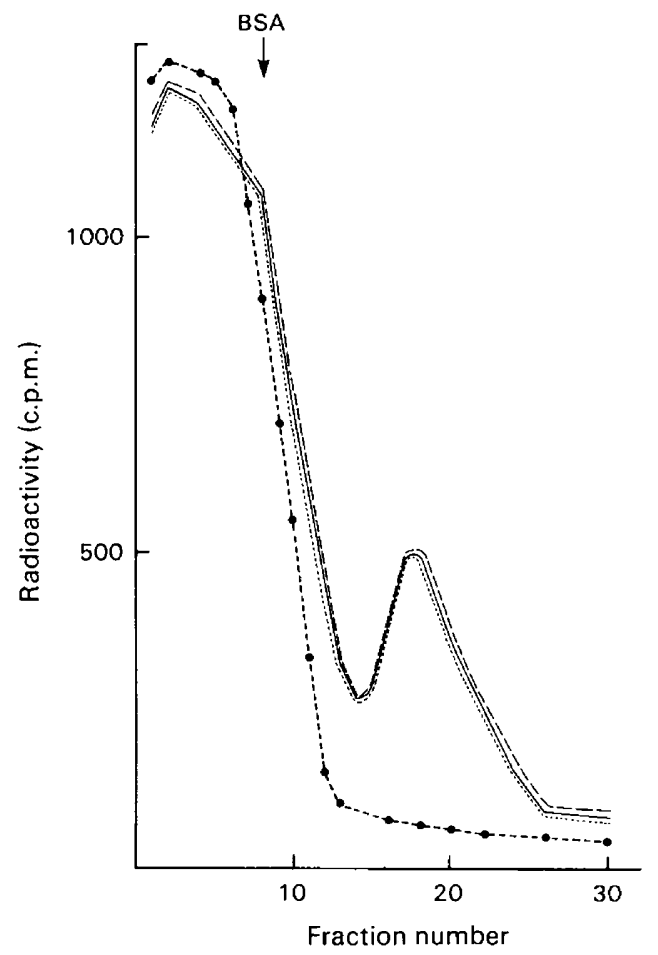

Text-fig. 2. Radioactive profiles from sucrose density-gradient centrifugation of canine epididymal cytosol preincubated with 2 pmol tritiated $5 \alpha$-dihydrotestosterone alone $(-)$ and subsequently in the presence of protease (--O), DNase (---) or RNase (......). The sedimentation marker is BSA with a coefficient of sedimentation of $4.6 \mathrm{~S}$.

The relative abilities of other natural and synthetic compounds to displace the bound $5 \alpha-$ dihydrotestosterone or oestradiol are shown in Text-fig. 3. At 100-fold excess, only testosterone and $5 a$-dihydrotestosterone achieved greater than $50 \%$ reduction in binding (Text-fig. $3 \mathrm{a}$ ). Cyproterone acetate and R 1881 were only just less effective followed, in decreasing efficiency, by the active metabolite of flutamide, $\alpha, \alpha, \alpha$,-trifluoro-2-methyl-4 ${ }^{1}$-nitro-m-lactotoluidide, $5 \alpha$ androstane- $3 \alpha, 17 \beta$-diol, $5 \alpha$-androstane- $3 \beta, 17 \beta$-diol, oestradiol-17\%, DES and $5 \alpha$-androstane$3 \alpha, 17 \alpha$-diol. When the concentration of competitor was increased to 1000 -fold that of the ligand, testosterone, cyproterone acetate, R1881 and the flutamide metabolite were equally effective.

The three naturally occurring oestrogens, oestrone, oestradiol-17 $\alpha$ and oestriol, competed well with the oestradiol receptor (Text-fig. 3b) whilst DES was nearly as effective as oestradiol$17 \beta$. Cyproterone acetate and $5 \alpha$-dihydrotestosterone were very poor competitors and tamoxifen and dihydrodibutylstilboestrol were relatively ineffectual. 


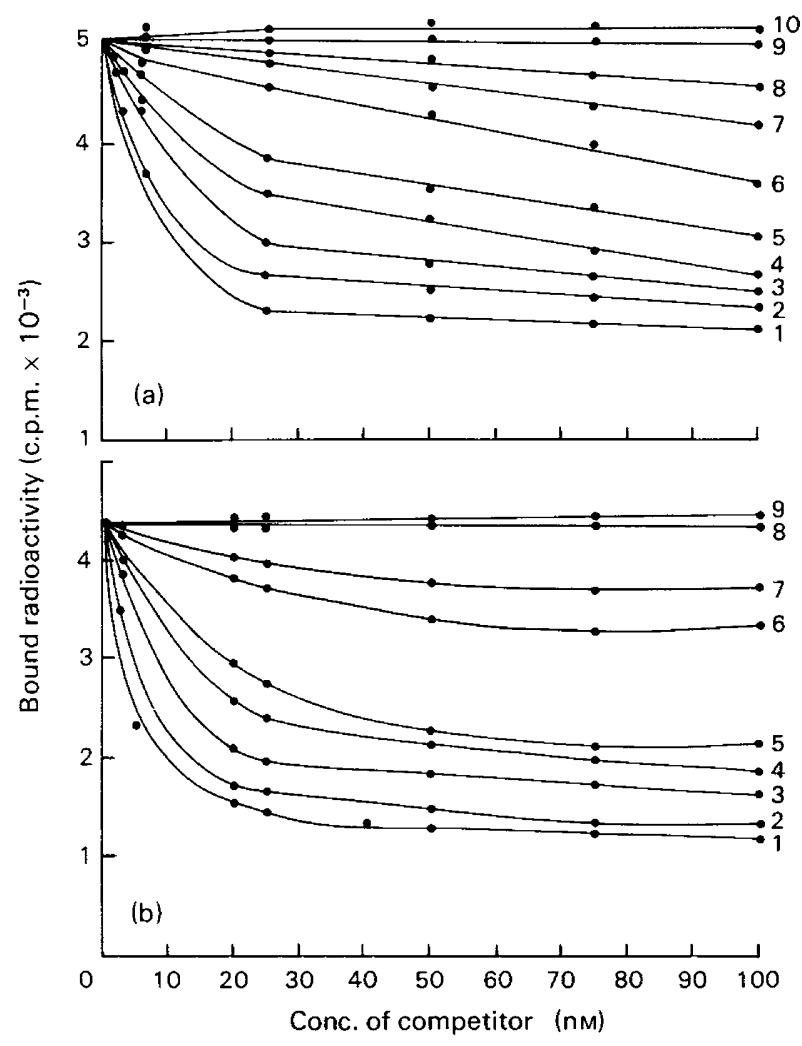

Text-fig. 3. The ability of various competitors to displace (a) tritiated $5 \alpha$-dihydrotestosterone (1 pmol) and (b) tritiated oestradiol-17 $\beta(1 \mathrm{pmol})$ from the cytosol receptor of the canine epididymis at concentrations up to 100 -fold that of the bound ligand. Unbound hormone was removed by dextran-coated charcoal. Compounds examined were: (a) 1, 5a-dihydrotestosterone; 2 , testosterone; 3 , cyproterone acetate; 4 , R $1881 ; 5, \alpha, \alpha, \alpha$-trifluoro- 2 -methyl-41 ${ }^{1}$-nitro-m-

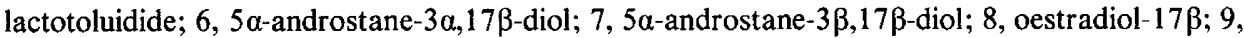
diethylstilboestrol; $10,5 \alpha$-androstane- $3 \alpha, 17 \alpha$-diol; (b) 1, oestradiol-17 $\beta ; 2$, diethylstilboestrol; 3 , oestrone; 4 , oestradiol- $17 \alpha ; 5$, oestriol; 6 , tamoxifen; 7 , dihydrodibutylstilboestrol; $8,5 \alpha$ dihydrotestosterone; 9 , cyproterone acetate.

Saturation analysis (Text-fig. 4) of the binding components provided values for the dissociation constants and receptor site concentrations that differed little between glands, irrespective of whether the animals had been castrated, treated with diethylstilboestrol or were untreated. The mean \pm s.d. dissociation constants for $5 \alpha$-dihydrotestosterone and oestradiol-17 $\beta$ were $2.7 \pm 2.66 \times 10^{-10} \mathrm{M}$ and $5.3 \pm 3.95 \times 10^{-10} \mathrm{M}$ respectively. The concentration of accessible receptor sites was $70.1 \pm 11.65 \mathrm{fmol} / \mathrm{mg}$ cytosol protein and $30.3 \pm 6.65 \mathrm{fmol} / \mathrm{mg}$ cytosol protein for the androgen and oestrogen respectively. These values indicate the high affinity and low capacity of both receptors.

On two occasions the epididymides were divided into three anatomically distinct regions, caput, corpus and cauda epididymidis and assessed for steroid receptor binding, In an intact animal a receptor protein was found for oestradiol-17 $\beta$ in each region but only in the more distal two parts for $5 \alpha$-dihydrotestosterone. When the experiment was repeated with tissue from a 3 day castrated animal, receptor activity was found in each region for both steroids with dissociation constants of $5.0 \times 10^{-10} \mathrm{M}, 3.5 \times 10^{-10} \mathrm{M}$ and $4.2 \times 10^{-10} \mathrm{M}$ for oestradiol-17 $\beta$, respectively and $6.7 \times 10^{-10} \mathrm{M}, 2.0 \times 10^{-10} \mathrm{M}$ and $1.9 \times 10^{-10} \mathrm{M}$ for $5 \alpha$-dihydrotestosterone. 


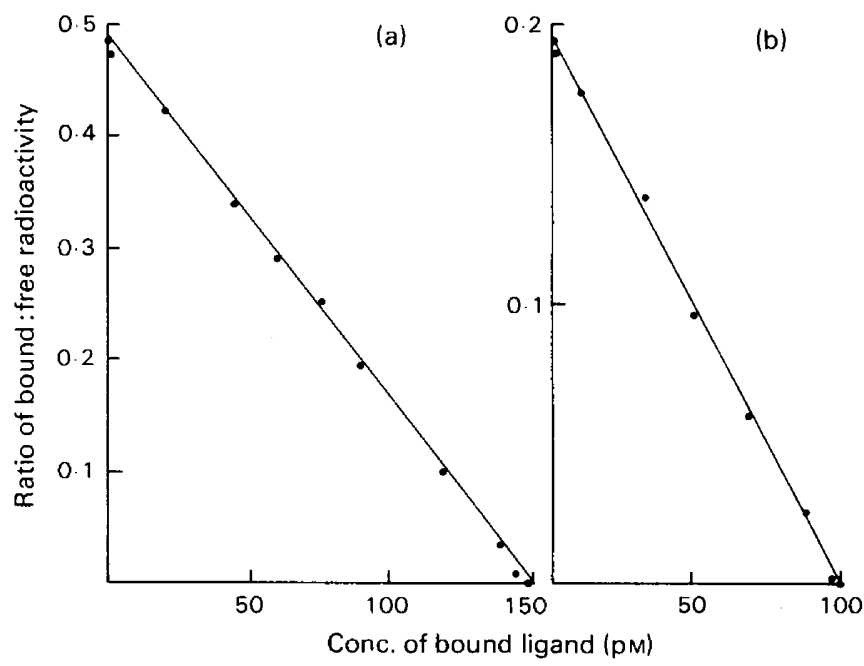

Text-fig. 4. Saturation analysis (Scatchard, 1949) of the interaction of the cytosol of the canine epididymis with (a) $5 \alpha$-dihydrotestosterone and (b) oestradiol-17 $\beta$. Aliquots of cytosol $(200 \mu \mathrm{l})$ were incubated with increasing concentration $(0.06-8.0 \mathrm{pmol})$ of tritiated hormone. A parallel series of incubations was undertaken for the assessment of non-specific binding in which 100 fold excess of the unlabelled steroid was included. Incubations were continued for $6 \mathrm{~h}$ at $0^{\circ} \mathrm{C}$. Unbound steroid was removed by dextran-coated charcoal.

\section{Discussion}

These studies have provided evidence for the presence of two receptor proteins for androgens and oestrogens respectively in the cytosol fraction of the canine epididymis. Each was shown to sediment in the $8 \mathrm{~S}$ region of a 5-20\% sucrose gradient, to be proteinaceous, in part at least, and to be of low capacity and high affinity. The possibility that the binding protein could be sexhormone binding globulin (SHBG) or androgen-binding protein (ABP) can be discounted for several reasons. (1) SHBG and ABP have been shown to sediment only in the $4 \mathrm{~S}$ region of a gradient (Ritzen \& French, 1974; Hansson et al.,1973a, b); (2) the canine epididymal androgen and oestrogen receptors were far more thermolabile than the plasma and testicular proteins; (3) cyproterone acetate was an effective inhibitor of androgen-binding in the epididymal cytosol but is ineffective in this respect towards ABP or SHBG (Tindall et al., 1974).

The epididymal proteins described here meet with some of the criteria demanded of a 'receptor' in that both showed high affinity and specificity for their ligands, were present in low saturable amounts and showed salt-dependent transformation with transfer to the nucleus (unpublished data).

The demonstration of a receptor for oestrogens in an organ that has long been considered merely an androgen-target organ is of special interest. It suggests that oestrogens play a role in the normal physiology of the gland and also provides another means of affecting its function, e.g. for contraceptive purposes. Peyre \& LaPorte (1966) indicated that oestradiol-17 $\beta$ was approximately $50 \%$ as effective as testosterone in increasing epididymal weight above that of castrated animals, as well as increasing the organ's total and free sialic acid content. Jehan \& Setty (1977) also showed an increase in the concentration of sialic acid as well as that of glycerylphosphoryl choline of the epididymides of oestrogen-treated castrated rats. 
Other aspects of epididymal function may also be under an oestrogen influence, for example, contractility which governs the transit time for spermatozoa before storage in the cauda epididymidis (Meistrich, Hughes \& Bruce, 1975). This raises the question of which cell types possess the respective receptors and the relative contribution the two classes of hormone make to the multiplicity of epididymal functions.

We are grateful to the Tenovus Organization, Cardiff, for generous financial support; the European Molecular Biology Organization (EMBO) on behalf of Y.V.; the Medical Research Council for a scholarship to B.A.J.E. and Chulalongkorn University, Bangkok, Thailand, for the provision of a fellowship to N.C. for work at the Tenovus Institute, Cardiff.

\section{References}

Baulieu, E.-E., Alberga, A., Jung, I., Lebeau, M.-C., Mercier-Bodard, C., Milgrom, E., Raynaud, J.-P., Raynaud-Jammet, C., Rochefort, H., Truong, H. \& Robe, P. (1971) Metabolism and protein binding of sex steroids in target organs: an approach to the mechanism of hormone action. Recent Prog. Horm. Res. 27, 351-419.

Bedford, J.M. (1966) Development of the fertilizing ability of spermatozoa in the epididymis of the rabbit. J. exp. Zool. 163, 319-330.

Bedford, J.M. (1967) Effects of duct ligation on the fertilizing ability of spermatozoa from different regions of the rabbit epididymis. J. exp. Zool. 166, $271-282$.

Benoit, J. (1926) Recherches anatomiques, cytologiques et histophysiologiques sur les voies excretices du testicle chez les mammiferes. Archs Anat. Histol. Embryol. 5, 173-412.

Blaquier, J.A. (1971) Selective uptake and metabolism of androgens by rat epididymis. The presence of a cytoplasmic receptor. Biochem. Biophys. Res. Commun. 45, 1076-1082.

Blaquier, J.A., Cameo, M.S. \& Charreau, E. (1970) Comparative uptake of androstenediol, testosterone and dihydrotestosterone by tissues of the male rat. $J$. Steroid Biochem. 1, 327-334.

Danzo, B.J. \& Eller, B.C. (1975) Androgen binding to cytosol prepared from epididymidis of sexually mature castrated rabbits: evidence for a cytoplasmic receptor. Steroids 25, 507-524.

Danzo, B.J., Orgebin-Crist, M.-C. \& Toft, D.O. (1973) Characterization of a cytoplasmic receptor for $5 \alpha$ dihydrotestosterone in the caput epididymidis of intact rabbits. Endocrinology 92, 310-317.

Danzo, B.J., Eller, B.C. \& Judy, L.A. (1975) Estradiol binding in cytosol from epididymides of immature rabbits. Molec. cell. Endocr. 2, 91-105.

Danzo, B.J., Wolfe, M.S. \& Curry, J. (1977) The presence of an estradiol binding component in cytosol from immature rat epididymides. Molec. cell. Endocr. 5, 271-279.

Evans, C.R. \& Pierrepoint, C.G. (1975) Demonstration of a specific cytosol receptor in the normal and hyperplastic canine prostate for $5 a$-androstane3a,17a-diol. J. Endocr. 64, 539-548.

Hamilton, D.W. (1975) Structure and function of the epithelium lining the ductuli efferentes, ductus epididymidis and ductus deferens in the rat. In Handbook of Physiology, Section 7, Vol. 5, pp. 259 301. Eds D. W. Hamilton \& R. O. Greep. Am. Physiol. Soc. Washington, D.C.

Hansson, V., Djøseland, O., Reusch, E., Attramadal, A. \& Torgersen, O. (1973a) An androgen binding protein in the testis cytosol fraction of adult rats. Comparison with the androgen binding protein in the epididymis. Steroids 21, 457-474.

Hansson, V., Djøseland, O., Reusch, E., Attramadal, A. \& Torgersen, O. (1973b) Intracellular receptors for $5 a$-dihydrotestosterone in the epididymis of adult rats. Comparison with the androgenic binding protein (ABP) in the testicular and epididymal fluid. Steroids 22, 19-33.

Heyns, W., Van Baelen, H. \& De Moor, P. (1967) Study of steroid-protein binding by means of competitive adsorption: application to cortisol binding in plasma. Clin. chim. Acta 18, 361-370.

Jehan, Q. \& Setty, B.S. (1977) Influence of sex steroids on the secretory function of the epididymis in castrated rats. Endokrinologie 69, 281-286.

King, R.J.B. \& Mainwaring, W.I.P. (1974) Steroid-Cell Interactions. Butterworths, London.

Lubicz-Nawrocki, C.M. \& Glover, T.D. (1973) The influence of the testis on the survival of spermatozoa in the epididymis of the golden hamster, Mesocricetus auratus. J. Reprod. Fert. 34, 315-329.

Meistrich, M.L., Hughes, T.J. \& Bruce, W.R. (1975) Alteration of epididymal sperm transport and maturation in mice by oestrogen and testosterone. Nature, Lond. 258, 145-147.

Nishikawa, Y. \& Waide, Y. (1952) Studies on the maturation of spermatozoa. I. Mechanism and speed of transition of spermatozoa in the epididymis and their functional changes. Bull. Nat. Inst. Agr. Sci. Series $G$, No. 3, 68-81.

O'Malley, B.W. \& Means, A.R. (1974) Female steroid hormones and target cell nuclei. Science, N.Y. 183, $610-620$.

Orgebin-Crist, M.-C. (1967) Maturation of spermatozoa in the rabbit epididymis. Fertilizing ability and embryonic mortality in does inseminated with epididymal spermatozoa. Annls Biol. anim. Biochim. Biophys. 7, 373-389. 
Orgebin-Crist, M.-C., Davies, J. \& Tichenon, P.L. (1972) Maturation of spermatozoa in the rabbit epididymis. In Regulation of Mammalian Reproduction, pp. 189-203. Eds S. J. Segal, R. Crozier \& P. A. Corfman. C. C. Thomas, Springfield.

Peyre, A. \& Laporte, P. (1966) Evolution des acides sialiques epididymaires chez le rat impubère et adulte. C. r. Séanc. Soc. Biol. 263, 1972-1975.

Pierrepoint, C.G., Davies, P. \& Wilson, D.W. (1974) The role of the epididymis and ductus deferens in the direct and unilateral control of the prostate and seminal vesicles of the rat. J. Reprod. Fert. 41, 413423.

Ritzen, E.M. \& French, F.S. (1974) Demonstration of an androgen-binding protein (ABP) in rabbit testis: secretion of efferent duct fluid and passage into epididymis. J. Steroid biochem. 5, 151-154.

Ritzen, E.M., Nayfeh, S.N., French, F.S. \& Dobbins, M.C. (1971) Demonstration of an androgen binding component in the rat epididymis cytosol and comparison with binding components in the prostate and other tissues. Endocrinology 89, 143-151.

Scatchard, G. (1949) The attraction of proteins for small molecules and ions. Science, N.Y. 51, 660-672.

Tindall, D.J., Hansson, V., Sar, M., Stumpf, W.E., French, F.S. \& Nayfeh, S.N. (1974) Further studies on the accumulation and binding of androgen in rat epididymis. Endocrinology 95, 119-1128.

Received 26 June 1978 